\title{
Preparation and properties of a coniferin enantiomer
}

\author{
Haruka Maeda' ${ }^{1}$ Taku Tsuyama ${ }^{2}$, Keiji Takabe ${ }^{1}$, Hiroshi Kamitakahara ${ }^{1}$ and Toshiyuki Takano ${ }^{1 *}$ (D)
}

\begin{abstract}
L-Coniferin (1L), which is an enantiomer of natural coniferin (D-coniferin (1D)), was prepared from L-glucose according to the conventional method for compound $\mathbf{1 D}$. The reactivity of L-glucose and its derivatives was found to be almost same as that of the corresponding $\mathrm{D}$-glucose and its derivatives during the preparation for compound $\mathbf{1} \mathbf{L}$. Compound $1 \mathrm{~L}$ showed resistance toward enzymatic hydrolysis by commercial $\beta$-glucosidase from Almond. However, unlike compound $\mathbf{1 D}$, compound $\mathbf{1} \mathbf{L}$ was not transported across the membrane obtained from differentiating xylem of a hybrid poplar in the present assay. The result suggested for the first time that the D-/L-configuration of the glucose moiety of coniferin is an important factor affecting coniferin transport across the membrane.
\end{abstract}

Keywords: Coniferin, Enantiomer, D-Glucose, L-Glucose, Transporter

\section{Introduction}

Natural coniferin (hereafter "D-coniferin (1D)") is a D-glucoside consisting of D-glucose and coniferyl alcohol. It is considered to be a form of coniferyl alcohol that functions in storage and transport in lignin biosynthesis [1-4]. There are three important pieces of information known about coniferin transport. First, compound 1D is found in the cambial sap of many tree species $[1,5]$. Second, coniferin $\beta$-glucosidase is located in the cell wall of coniferous and broad-leaf trees $[6,7]$. Third, the incorporation of radioactivity into cell wall lignin is observed when radiolabeled compound $1 \mathrm{D}$ is fed to a variety of plants [8]. Taken together, this suggests that compound 1D might be transported through the membrane to the cell wall and be subjected to enzymatic hydrolysis by $\beta$-glucosidase to form coniferyl alcohol for lignification. However, this hypothesis has not yet been proven and there is still debate as to whether coniferyl alcohol is transported in its free or glucoside form [3, 4].

Theoretically, there should be a non-natural coniferin, an enantiomer of compound 1D (hereafter "L-coniferin

\footnotetext{
*Correspondence: takatmys@kais.kyoto-u.ac.jp

${ }^{1}$ Division of Forest and Biomaterials Science, Graduate School of Agriculture, Kyoto University, Kitashirakawa oiwake-cho, Sakyo-ku, Kyoto 606-8502, Japan

Full list of author information is available at the end of the article
}

(1L)"), which consists of L-glucose and coniferyl alcohol as shown in Fig. 1, because there is an enantiomer of D-glucose (L-glucose). To the best of our knowledge, compound $1 \mathrm{~L}$ was not found in nature. It is widely known that a pair of enantiomers has the same chemical and physical properties except for their optical properties such as specific rotation. In addition, $\mathrm{L}$-glucoside is thought not to be hydrolyzed by $\beta$-glucosidase because of the substrate specificity of the enzyme [9], although the experimental data have not been found. Therefore, compound $\mathbf{1 L}$ might be useful as a transport tracer in an administration experiment, because it might be transported to the site of lignification to a similar degree as compound 1D, but would not be hydrolyzed by the enzyme as it accumulated. However, compound $\mathbf{1 L}$ has not been available, because there is no report about the preparation of compound $\mathbf{1 L}$.

This research describes the first preparation of compound 1L and its properties including its enzymatic hydrolysis and membrane transport ability.

\section{Experimental \\ Materials}

L-Glucose and $\beta$-glucosidase (from Almond, $121 \mathrm{U} /$ $\mathrm{mg}$ ) were purchased from Tokyo Chemical Industry Co. (Tokyo, Japan) and Oriental Yeast Co. (Tokyo, Japan), respectively. All other chemicals were purchased from 


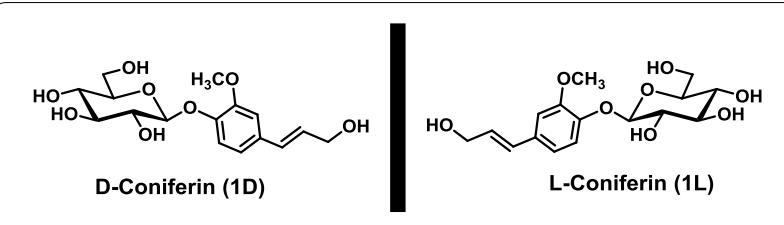

Fig. 1 Natural coniferin (1D) and its enantiomer (1L)

commercial sources and used without further purification unless otherwise noted.

\section{Measurements}

${ }^{1} \mathrm{H}$ and ${ }^{13} \mathrm{C}$ NMR spectra were recorded on a Varian INOVA300 MHz FT-NMR (300 MHz) spectrometer (Agilent Technologies, Santa Clara, CA, USA) using tetramethylsilane as an internal standard in DMSO- $d_{6}$ for compounds 1L and 1D or $\mathrm{CDCl}_{3}$ for others. Chemical shift $(\delta)$ and coupling constant $(J)$ are given in ppm (parts per million) and $\mathrm{Hz}$, respectively. Matrix-assisted laser desorption/ionization time-of-flight mass spectrometry (MALDI-TOF MS) measurements were recorded on a Bruker MALDI-TOF MS REFLEX III (Bruker, Billerica, MA, USA) in the positive and linear ion modes. A nitrogen laser was used for the ionization of the samples. All spectra were obtained using 2,5-dihydroxybenzoic acid as a matrix. Specific rotations were recorded on a JASCO P-2200 polarimeter (JASCO, Hachioji, Japan) in $\mathrm{H}_{2} \mathrm{O}$ for compounds $1 \mathrm{~L}$ and 1D or $\mathrm{CHCl}_{3}$ for others, and were determined as the average values of five measurements. Melting points (m.p.) were measured in a micro-melting point apparatus (Yanagimoto Seisakusho, Kyoto, Japan). UV-Vis spectra were recorded on a JASCO V-560 spectrophotometer (JASCO).

\section{Preparation of L-coniferin (1L)}

Compound $1 \mathrm{~L}$ was prepared from $\mathrm{L}$-glucose (2L) according to the conventional method for compound 1D [10] as shown in Fig. 2.

\section{I-Glucose pentaacetate ( $3 \mathrm{~L}$ )}

Compound $2 \mathrm{~L}(5 \mathrm{~g}, 27.8 \mathrm{mmol})$ and $\mathrm{CH}_{3} \mathrm{COONa}(2.5 \mathrm{~g}$, $30.5 \mathrm{mmol})$ were suspended in $\mathrm{Ac}_{2} \mathrm{O}(25 \mathrm{~mL})$. The suspension was stirred at $80{ }^{\circ} \mathrm{C}$ for $3.5 \mathrm{~h}$, cooled to ambient temperature and extracted with EtOAc. The organic layer was washed with a saturated $\mathrm{NaHCO}_{3}$ solution, distilled water, and brine, dried over $\mathrm{Na}_{2} \mathrm{SO}_{4}$ and evaporated to give a colorless residue. The residue was recrystallized from $\mathrm{EtOH}$ to give compound 3L (9.63 g, 88.9\% yield).

Compound 3L: $[\alpha]_{D}^{25}=-20.7^{\circ}\left(c=1.03\right.$, in $\left.\mathrm{CHCl}_{3}\right)$; ${ }^{1} \mathrm{H}$ and ${ }^{13} \mathrm{C}$ NMR spectra data of compound $3 \mathbf{L}$ were in agreement with the published data of L-glucose pentaacetate [11]; MALDI-TOF MS: $\mathrm{m} / z$ calcd. for $[\mathrm{M}+\mathrm{Na}]^{+}$ $\mathrm{C}_{16} \mathrm{H}_{22} \mathrm{NaO}_{11}$ : 413.34, found: 413.56 .

\section{2,3,4,6-Tetra-O-acetyl-a-I-glucopyranosyl bromide (4L)}

Compound 3L (1000 mg, $2.56 \mathrm{mmol})$ was dissolved in $\mathrm{CH}_{2} \mathrm{Cl}_{2}(2 \mathrm{~mL}) .33 \%-\mathrm{HBr}$ in $\mathrm{AcOH}(2.5 \mathrm{~mL}, 14.4 \mathrm{mmol})$ was added to the solution at $0{ }^{\circ} \mathrm{C}$. After stirring the reaction solution at ambient temperature for $2 \mathrm{~h}$, distilled water $(10 \mathrm{~mL})$ was added to the solution at $0{ }^{\circ} \mathrm{C}$. The reaction mixture was extracted with EtOAc. The organic layer was washed with distilled water, a saturated $\mathrm{NaHCO}_{3}$ solution, and brine, dried over $\mathrm{Na}_{2} \mathrm{SO}_{4}$ and evaporated to give a colorless residue. The residue was recrystallized from $\mathrm{EtOH}$ to give compound $\mathbf{4 L}$ ( $845 \mathrm{mg}, 80.2 \%$ yield).

Compound 4L: $[\alpha]_{D}^{25}=-194.3^{\circ}\left(c=1.04\right.$, in $\left.\mathrm{CHCl}_{3}\right)$; ${ }^{1} \mathrm{H}$ NMR $\left(\mathrm{CDCl}_{3}\right): \delta 6.62(\mathrm{~d}, 1 \mathrm{H}, J=4.2, \mathrm{H}-1), 5.56(\mathrm{t}$, $1 \mathrm{H}, J=9.8, \mathrm{H}-3), 5.16(\mathrm{t}, 1 \mathrm{H}, J=9.8, \mathrm{H}-4), 4.84(\mathrm{dd}$,

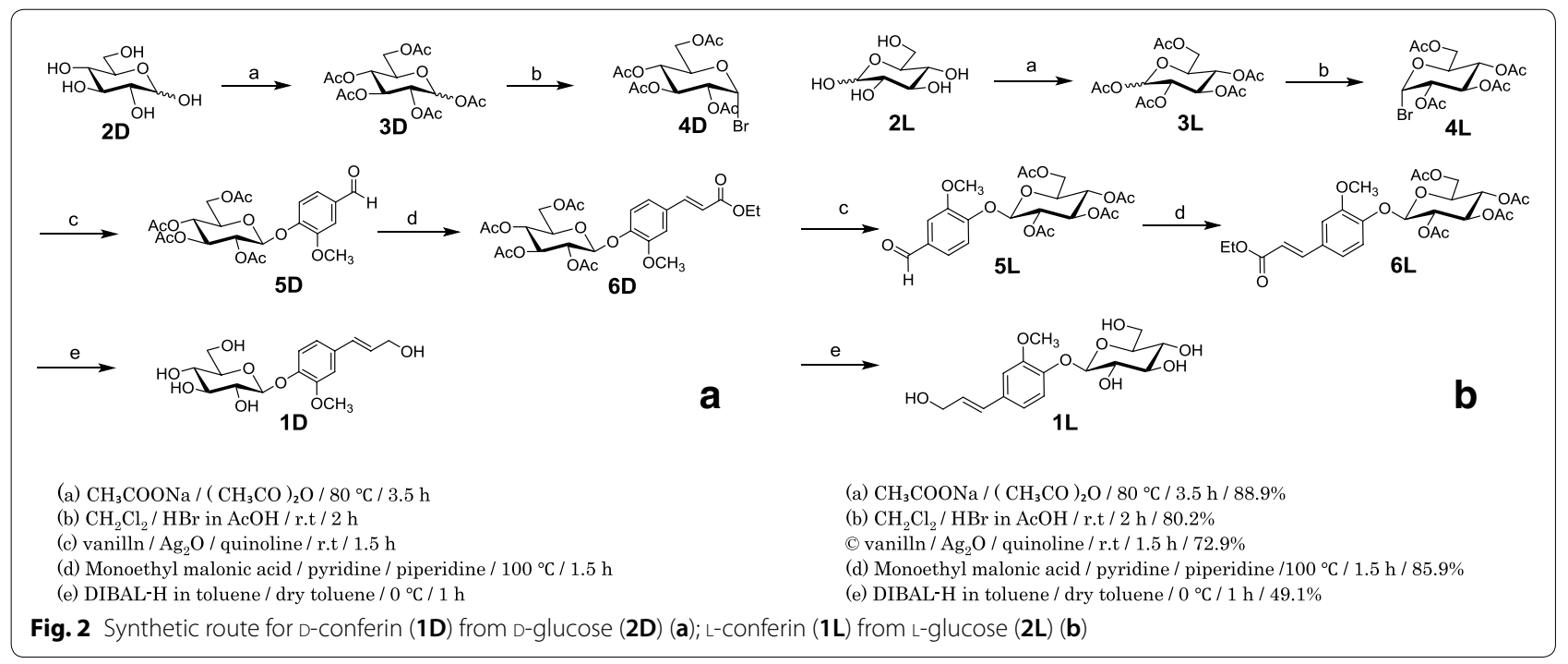


$1 \mathrm{H}, J=9.8,4.2, \mathrm{H}-2), 4.33(\mathrm{dd}, 1 \mathrm{H}, J=14.1,4.2, \mathrm{H}-6 \mathrm{a})$, 4.30 (ddd, $J=9.8,4.2,1.5, \mathrm{H}-5), 4.13$ (dd, $1 \mathrm{H}, J=14.1$, 1.5, H-6b), 2.11, 2.10, 2.06, $2.04\left(\mathrm{~s}, 3 \mathrm{H}\right.$, acetyl $\left.\mathrm{CH}_{3}\right)$; ${ }^{13} \mathrm{C}$ NMR $\left(75 \mathrm{MHz}, \mathrm{CDCl}_{3}\right): \delta 170.6,170.0,169.9$, 169.6 (acetyl $\mathrm{C}=\mathrm{O}), 86.7$ (C-1), 72.2 (C-5), 70.7 (C-2), 70.3 (C-3), 67.3 (C-4), 61.0 (C-6), 20.8, 20.8, 20.7, 20.7 (acetyl $\mathrm{CH}_{3}$ ); MALDI-TOF MS: $\mathrm{m} / z$ calcd. for $[\mathrm{M}+\mathrm{Na}]^{+}$ $\mathrm{C}_{14} \mathrm{H}_{19} \mathrm{BrNaO}_{9}$ : 433.20, found: 434.99 .

\section{(4-Formyl-2-methoxy)phenyl 2,3,4,6-tetra-O-acetyl- $\beta$-I-gluco pyranoside (5L)}

Compound 4L: (700 mg, $1.65 \mathrm{mmol}$ ) and vanillin (250 mg, $1.65 \mathrm{mmol}$ ) were dissolved in quinoline (4.5 mL). $\mathrm{Ag}_{2} \mathrm{O}(390 \mathrm{mg})$ was added to the solution at $0{ }^{\circ} \mathrm{C}$. The reaction mixture was stirred at ambient temperature for $1.5 \mathrm{~h}$, filtered through Celite (535RVS, Nacalai Tesque (Kyoto, Japan)), and extracted with EtOAc. The organic layer was washed with a $1 \mathrm{M} \mathrm{HCl}$ solution, a saturated $\mathrm{NaHCO}_{3}$ solution, and brine, dried over $\mathrm{Na}_{2} \mathrm{SO}_{4}$ and evaporated to give a light brown residue. The residue was recrystallized from $\mathrm{EtOH}$ to give compound $\mathbf{5 L}$ (599 mg, 72.9\% yield).

Compound 5L: $[\alpha]_{D}^{25}=+42.9^{\circ}\left(c=0.53\right.$, in $\left.\mathrm{CHCl}_{3}\right) ;{ }^{1} \mathrm{H}$ NMR (300 MHz, $\left.\mathrm{CDCl}_{3}\right): \delta 9.90(\mathrm{~s}, 1 \mathrm{H}, \mathrm{CHO}), 7.44(\mathrm{~d}$, $\left.1 \mathrm{H}, J=2.1, \mathrm{H}-2^{\prime}\right), 7.42\left(\mathrm{dd}, 1 \mathrm{H}, J=8.7,2.1, \mathrm{H}-6^{\prime}\right), 7.22$ $\left(\mathrm{d}, 1 \mathrm{H}, J=8.7, \mathrm{H}-5^{\prime}\right), 5.37-5.27$ (m, 2H, H-2, H-3), 5.22$5.15(\mathrm{~m}, 1 \mathrm{H}, \mathrm{H}-4), 5.11(\mathrm{~d}, 1 \mathrm{H}, J=7.8, \mathrm{H}-1), 4.28$ (dd, $1 \mathrm{H}, J=12.3,5.4,1 \mathrm{H}, \mathrm{H}-6 \mathrm{a}), 4.19$ (dd, $1 \mathrm{H}, J=12.3,2.7$, $\mathrm{H}-6 \mathrm{~b}), 3.90$ (s, 3H, $\mathrm{OCH}_{3}$ ), 3.85 (ddd, $1 \mathrm{H}, J=9.8,5.4,2.7$, $\mathrm{H}-5), 2.08,2.08,2.05,2.05$ (s, 3H, acetyl $\left.\mathrm{CH}_{3}\right) ;{ }^{13} \mathrm{C} \mathrm{NMR}$ $\left(75 \mathrm{MHz}, \mathrm{CDCl}_{3}\right): \delta 191.1(\mathrm{C}-\alpha), 170.7,170.4,169.5$, 169.4 (acetyl $\mathrm{C}=\mathrm{O}), 151.2\left(\mathrm{C}-4^{\prime}\right), 151.1\left(\mathrm{C}-3^{\prime}\right), 133.0$ $\left(\mathrm{C}-1^{\prime}\right), 125.5\left(\mathrm{C}-6^{\prime}\right), 118.3\left(\mathrm{C}-5^{\prime}\right), 110.8\left(\mathrm{C}-2^{\prime}\right), 99.9(\mathrm{C}-1)$, 72.5 (C-3), 72.4 (C-5), 71.1 (C-2), 68.4 (C-4), 62.0 (C-6), $56.2\left(\mathrm{OCH}_{3}\right), 20.9,20.9,20.8,20.8$ (acetyl $\left.\mathrm{CH}_{3}\right)$; MALDITOF MS: $m / z$ calcd. for $[\mathrm{M}+\mathrm{Na}]^{+} \mathrm{C}_{22} \mathrm{H}_{26} \mathrm{NaO}_{12}:$ 505.44, found: 505.35 .

\section{(4-Ethoxycarbonyl-2-methoxy)phenyl 2,3,4,6-tetra-O-acetyl-}

\section{$\beta$-I-glucopyranoside (6L)}

Compound 5L (1000 mg, $2.07 \mathrm{mmol}$ ) and ethyl malonic acid (520 mg, $3.96 \mathrm{mmol}$ ) were dissolved in pyridine $(16.5 \mathrm{~mL})$. After the addition of piperidine $(0.275 \mathrm{~mL}$, $2.78 \mathrm{mmol})$, the reaction solution was stirred at $100{ }^{\circ} \mathrm{C}$ for $1.5 \mathrm{~h}$ and concentrated by azeotrope distillation with EtOH to give a colorless residue. The residue was recrystallized from EtOH to give compound 6L (979 mg, 85.9\% yield).

Compound 6L: $[\alpha]_{D}^{25}=+27.2^{\circ}\left(c=0.56\right.$, in $\left.\mathrm{CHCl}_{3}\right) ;{ }^{1} \mathrm{H}$ NMR (300 MHz, $\left.\mathrm{CDCl}_{3}\right): \delta 7.62(\mathrm{~d}, 1 \mathrm{H}, J=16.2, \mathrm{H}-\alpha)$, $7.10\left(\mathrm{~d}, 1 \mathrm{H}, J=8.4, \mathrm{H}-5^{\prime}\right), 7.07$ (d, $\left.1 \mathrm{H}, J=1.5, \mathrm{H}-2^{\prime}\right), 7.05$ (dd, $\left.1 \mathrm{H}, J=8.4,1.5, \mathrm{H}-6^{\prime}\right), 6.35$ (d, $\left.1 \mathrm{H}, J=16.2, \mathrm{H}-\beta\right)$, 5.40-5.26 (m, 2H, H-2, H-3), 5.20-5.13 (m, 1H, H-4),
5.02-5.00 (m, 1H, H-1), 4.28 (dd, $1 \mathrm{H}, J=12.5,5.1, \mathrm{H}-6 \mathrm{a})$, 4.26 (dd, $\left.2 \mathrm{H}, J=14.1,7.2, \mathrm{CH}_{2}\right), 4.17(\mathrm{dd}, 1 \mathrm{H}, J=12.5,2.4$, $\mathrm{H}-6 \mathrm{~b}), 3.85$ (s, $3 \mathrm{H}, \mathrm{OCH}_{3}$ ), 3.80 (ddd, $1 \mathrm{H}, J=10.2$, 5.1, 2.4, H-5), 2.08, 2.05, 2.05, 2.04 (s, 3H, acetyl $\left.\mathrm{CH}_{3}\right), 1.34$ (t, $3 \mathrm{H}, J=7.2$, ethyl $\left.\mathrm{CH}_{3}\right) ;{ }^{13} \mathrm{C} \mathrm{NMR}\left(75 \mathrm{MHz}, \mathrm{CDCl}_{3}\right)$ : $\delta$ 170.5, 170.3, 169.4, 169.3 (acetyl $\mathrm{C}=\mathrm{O}), 166.9(\mathrm{C}-\gamma)$, 150.7 (C-3'), 147.7 (C-4'), 143.9 (C- $\alpha), 131.0\left(\mathrm{C}-1^{\prime}\right), 121.6$ $\left(\mathrm{C}-6^{\prime}\right), 119.5\left(\mathrm{C}-5^{\prime}\right), 117.6(\mathrm{C}-\beta), 111.3\left(\mathrm{C}-2^{\prime}\right), 100.3(\mathrm{C}-1)$, 72.4 (C-3), 72.0 (C-5), 71.0 (C-2), 68.3 (C-4), 61.8 (C-6), 60.5 (ethyl $\left.\mathrm{CH}_{2}\right), 56.0\left(\mathrm{OCH}_{3}\right), 20.7,20.6,20.6,20.6$ (acetyl $\mathrm{CH}_{3}$ ), 14.3 (ethyl $\mathrm{CH}_{3}$ ); MALDI-TOF MS: $\mathrm{m} / z$ calcd. for $[\mathrm{M}+\mathrm{Na}]^{+} \mathrm{C}_{26} \mathrm{H}_{32} \mathrm{NaO}_{13}: 575.53$, found: 575.57 .

\section{(4-(3-Hydroxy-2-propenyl)-2-methoxy)phenyl $\beta$-I-glucopyranoside (I-coniferin) (1L)}

Compound 6L (900 mg, $1.63 \mathrm{mmol}$ ) was dissolved in toluene $(22 \mathrm{~mL})$. The $1.01 \mathrm{~mol} / \mathrm{L}$ of DIBAL-H in toluene $(15 \mathrm{~mL}, 15.1 \mathrm{mmol})$ was added dropwise to the solution at $0{ }^{\circ} \mathrm{C}$ for $10 \mathrm{~min}$. The reaction mixture was stirred at $0{ }^{\circ} \mathrm{C}$ for $1 \mathrm{~h}$ and $\mathrm{EtOH}(20 \mathrm{~mL})$ was added slowly to the mixture. The reaction mixture was stirred at $0{ }^{\circ} \mathrm{C}$ for another $30 \mathrm{~min}$, concentrated and filtered with hot water. The filtrate was concentrated by azeotrope distillation with $\mathrm{EtOH}$ to give a colorless residue. The residue was purified by preparative thin-layer chromatography using a silica gel plate (silica gel $60 \mathrm{~F}_{254}, 2$-mm thickness, Merck, Darmstadt, Germany) developed with $20 \%$ $\mathrm{MeOH} / \mathrm{CH}_{2} \mathrm{Cl}_{2}(\mathrm{v} / \mathrm{v})$ and recrystallized from water three times to give compound 1L (295 mg, 49.1\% yield).

Compound 1L: m.p.: $179-182{ }^{\circ} \mathrm{C} ;[\alpha]_{D}^{25}=+65.8^{\circ}$ $\left(c=0.5\right.$, in $\left.\mathrm{CHCl}_{3}\right) ;{ }^{1} \mathrm{H}$ NMR $\left(300 \mathrm{MHz}, \mathrm{DMSO}-d_{6}\right): \delta$ 7.06 (d, $\left.1 \mathrm{H}, J=1.8, \mathrm{H}-2^{\prime}\right), 7.02\left(\mathrm{~d}, 1 \mathrm{H}, J=8.4, \mathrm{H}-5^{\prime}\right), 6.90$ (dd, $\left.1 \mathrm{H}, J=8.4,1.8, \mathrm{H}-6^{\prime}\right), 6.48(\mathrm{~d}, 1 \mathrm{H}, J=15.9, \mathrm{H}-\alpha), 6.28$ $(\mathrm{dt}, 1 \mathrm{H}, J=15.9,5.1, \mathrm{H}-\beta), 5.25(\mathrm{~d}, 1 \mathrm{H}, J=4.8, \mathrm{OH}-3), 5.10$ (d, $1 \mathrm{H}, J=4.8, \mathrm{OH}-2), 5.04(\mathrm{~d}, 1 \mathrm{H}, J=4.8, \mathrm{OH}-4), 4.89$ (d, $1 \mathrm{H}, J=8.1, \mathrm{H}-1), 4.85$ (d, $1 \mathrm{H}, J=5.4, \mathrm{OH}-\gamma), 4.57(\mathrm{t}, 1 \mathrm{H}$, $J=5.4, \mathrm{OH}-6), 4.10$ (dd, $1 \mathrm{H}, J=5.1,1.2, \mathrm{H}-\gamma \mathrm{a}), 4.09$ (dd, $1 \mathrm{H}, J=5.1,1.2, \mathrm{H}-\gamma \mathrm{b}), 3.79\left(\mathrm{~s}, 3 \mathrm{H}, \mathrm{OCH}_{3}\right), 3.68-3.65$ (m, 1H, H-6a), 3.52-3.17 (m, 5H, H-2, H-3, H-4, H-5, $\mathrm{H}-6 \mathrm{~b}) ;{ }^{13} \mathrm{C}$ NMR $\left(75 \mathrm{MHz}, \mathrm{DMSO}-d_{6}\right): \delta 149.4\left(\mathrm{C}-3^{\prime}\right)$, 146.4 (C-4'), $131.4\left(\mathrm{C}-1^{\prime}\right), 129.4(\mathrm{C}-\beta), 128.9(\mathrm{C}-\alpha), 119.5$

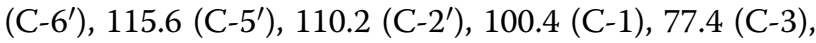
77.3 (C-5), 73.7 (C-2), 70.7 (C-4), 62.1 (C-8), 61.1 (C-6), $56.0\left(\mathrm{OCH}_{3}\right)$; MALDI-TOF MS: $m / z$ calcd. for $[\mathrm{M}+\mathrm{Na}]^{+}$ $\mathrm{C}_{16} \mathrm{H}_{22} \mathrm{NaO}_{8}: 365.34$, found: 365.30 .

\section{Preparation of D-coniferin (1D)}

Compound 1D was also prepared by the conventional method as shown in Fig. 2a [10]. Compound 3D: $[\alpha]_{D}^{25}=+21.4^{\circ}\left(c=1.34\right.$, in $\left.\mathrm{CHCl}_{3}\right) ;$ 4D: $[\alpha]_{D}^{25}=+193.5^{\circ}$ $\left(c=1.13\right.$, in $\left.\mathrm{CHCl}_{3}\right)$, 5D: $[\alpha]_{D}^{25}=-43.7^{\circ}(c=0.52$, in $\left.\mathrm{CHCl}_{3}\right)$, 6D: $[\alpha]_{D}^{25}=-26.6^{\circ}\left(c=0.56\right.$, in $\left.\mathrm{CHCl}_{3}\right)$, 1D: 
m.p. $181-183{ }^{\circ} \mathrm{C}$ (literature: $183-185^{\circ} \mathrm{C}[10], 185-188{ }^{\circ} \mathrm{C}$ $[12]) ;[\alpha]_{D}^{25}=-64.8^{\circ}\left(c=0.43\right.$, in $\left.\mathrm{CHCl}_{3}\right)$.

\section{Enzymatic hydrolysis of $\mathrm{D}$ - and L-coniferin (1D and 1L)} by $\beta$-glucosidase

An aqueous solution of $\beta$-glucosidase $\left(6 \times 10^{-5} \mathrm{~g} / \mathrm{L}\right.$, $5 \mathrm{~mL}$ ) was added to an aqueous solution of coniferin $(0.3 \mathrm{mmol} / \mathrm{L}, 10 \mathrm{~mL})$. The reaction solution was stirred at $40{ }^{\circ} \mathrm{C}$. An aliquot of the reaction solution $(1 \mathrm{~mL})$ was taken out at the prescribed time and poured into distilled water $(3 \mathrm{~mL})$ and then $0.1 \mathrm{~mL}$ of a $2.5 \mathrm{mM} \mathrm{NaOH}$ aqueous solution was immediately added. The mixed solution was subjected to UV-Vis measurement. The amount of coniferyl alcohol formed was determined using a calibration curve of coniferyl alcohol at $311 \mathrm{~nm}$.

\section{Transport assay of D- and L-coniferin (1D and 1L)}

The preparation of microsomal fractions from differentiating xylem of poplar (Populus sieboldii $\times$ P. grandidentata) and the transport assay were carried out according to the methods used in previous studies $[3,13]$. Uptake of coniferin by membrane vesicles was measured at $28{ }^{\circ} \mathrm{C}$ for $20 \mathrm{~min}$ in $100 \mu \mathrm{L}$ of reaction mixture [50 mM HEPES-KOH (pH 7.5), 5 mM Mg/ATP, $50 \mu \mathrm{M}$ substrate and membrane vesicles (ca. $10 \mu \mathrm{g}$ protein)], unless otherwise stated. Data are reported as technical replicates.

\section{Results and discussion}

\section{Preparation of $\mathrm{D}$ - and L-coniferin (1D and 1L)}

Compound $\mathbf{1 L}$ was prepared from compound $\mathbf{2 L}$ according to the conventional method for compound 1D [10] as shown in Fig. 2. Compound 1D was also prepared as a control compound. All the reaction steps [(a) acetylation, (b) bromination, (c) glycosidation, (d) Knoevenagel condensation, (e) reduction with DIBAL-H], proceeded smoothly to afford the final compound $\mathbf{6 L}$. Indeed, the reactivity of the $\mathrm{L}$-glucose/L-glucose derivative (compounds $2 \mathbf{L}$ to $6 \mathbf{L}$ ) was found to be almost the same as the $\mathrm{D}$-glucose/D-glucose derivative (compounds 2D to 6D) during the preparation of compound 1L. Reports of similar reactivities among L-glucose and D-glucose derivatives are known in the literature for the synthesis of digitoxigenin glycoside [14]. All products (Compounds 1L, 3L to $6 \mathbf{L}$ ) were characterized by acquiring their ${ }^{1} \mathrm{H}$ and ${ }^{13} \mathrm{C}$ NMR and MALDI-TOF MS spectra, and their specific rotation. The ${ }^{1} \mathrm{H}$ and ${ }^{13} \mathrm{C}$ NMR spectra of all the L-glucose derivatives had the same peak pattern as those of the D-glucose derivatives, but the sign of the specific rotation of the L-glucose derivatives was opposite to that of the specific rotation of the D-glucose derivatives (Additional file 1: Figs. S1-S10).

As an example, the ${ }^{1} \mathrm{H}$ and ${ }^{13} \mathrm{C}$ NMR spectra of compounds $1 \mathrm{~L}$ and $1 \mathrm{D}$ are shown in Fig. 3. The spectra of compound $1 \mathrm{~L}$ were the same as those of compound 1D. The value of $[\mathrm{M}+\mathrm{Na}]^{+}$for compound $1 \mathrm{~L}$ also corresponded to its calculated value from the MALDITOF-MS data of compound $\mathbf{1 L}$. The specific rotations of compounds $1 \mathrm{~L}$ and $1 \mathrm{D}$ were $+65.8^{\circ}$ and $-64.8^{\circ}$, respectively. These results clearly indicate that compound $\mathbf{1 L}$ was an enantiomer of compound 1D.

\section{Enzymatic hydrolysis of D- and L-coniferin (1D and 1L) by $\beta$-glucosidase}

The enzymatic hydrolysis of compounds $1 \mathrm{~L}$ and 1D by the commercial $\beta$-glucosidase from Almond was evaluated based on the formation of coniferyl alcohol in the reaction. The determination of the coniferyl alcohol formed in the reaction mixture was performed by a UVVis method (detection wavelength: $311 \mathrm{~nm}$ ), because the peak for coniferyl alcohol in an alkali solution at

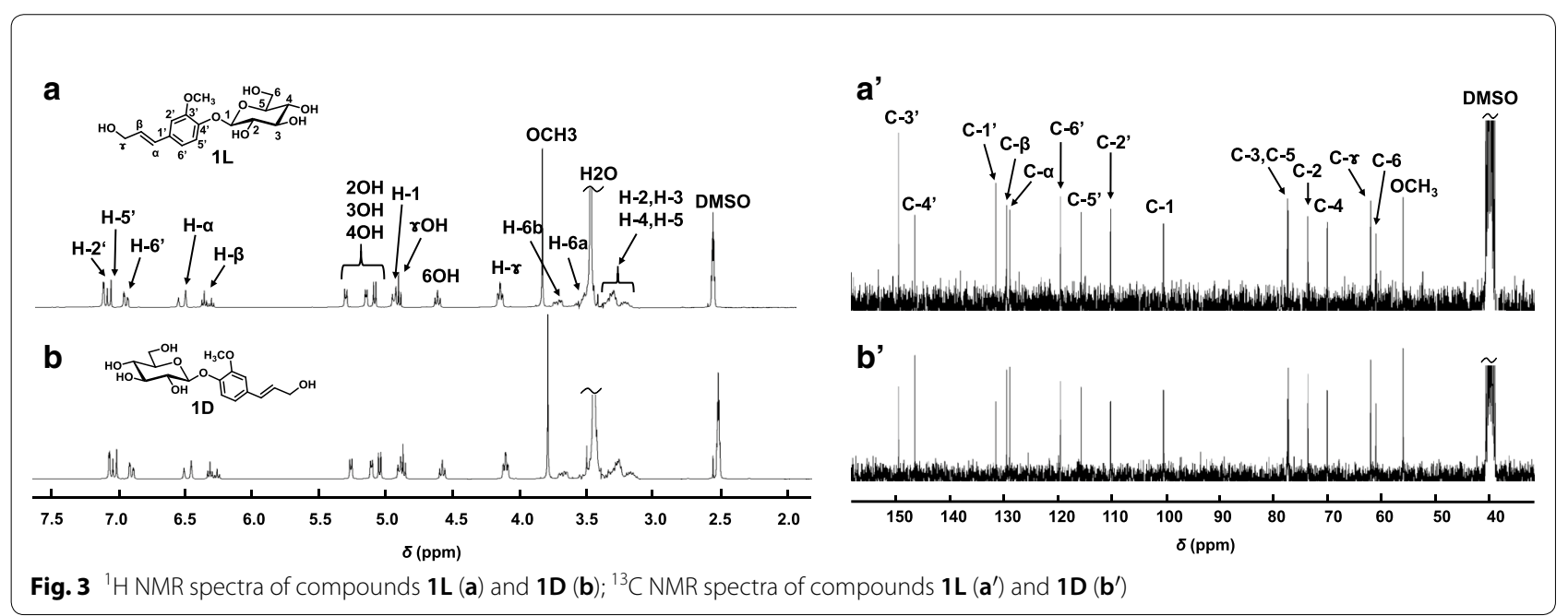


$311 \mathrm{~nm}$ did not overlap with any peaks from coniferin or the $\beta$-glucosidase (Fig. 4a). The percent hydrolysis of compounds 1L and 1D is shown in Fig. 4b. The percent hydrolysis of compound 1D increased with an increase of time and reached almost $100 \%$ after $24 \mathrm{~h}$. By contrast, the hydrolysis of compound $1 \mathrm{~L}$ was minimal with only $5.4 \%$ hydrolyzed after $24 \mathrm{~h}$. The results clearly show that compound $\mathbf{1 L}$ was resistant to enzymatic hydrolysis by the $\beta$-glucosidase, although further investigation (for example, the experiments using other $\beta$-glucosidase) is required.

\section{Transport assay of $\mathrm{D}$ - and $\mathrm{L}$-coniferin (1D and 1L)}

ATP-dependent compound 1D transport in the lignifying tissues of woody plants was suggested from the transport assay results of compound 1D [3]. That is, strong transport activity of compound 1D was observed in the presence of ATP, whereas weak transport activity was observed in the absence of ATP. Compound 1L was also tested in the transport assay. Figure 5 shows the uptake of compounds 1L and 1D into crude microsomal membrane vesicles derived from plasma membrane, vacuolar membrane, Golgi membrane and other endomembranes obtained from differentiating xylem of hybrid poplar. Surprisingly, only weak uptake activity was observed for compound $1 \mathrm{~L}$ in the presence of ATP and no uptake activity was observed in the absence of ATP. Thus, there was a significant difference of uptake activity between

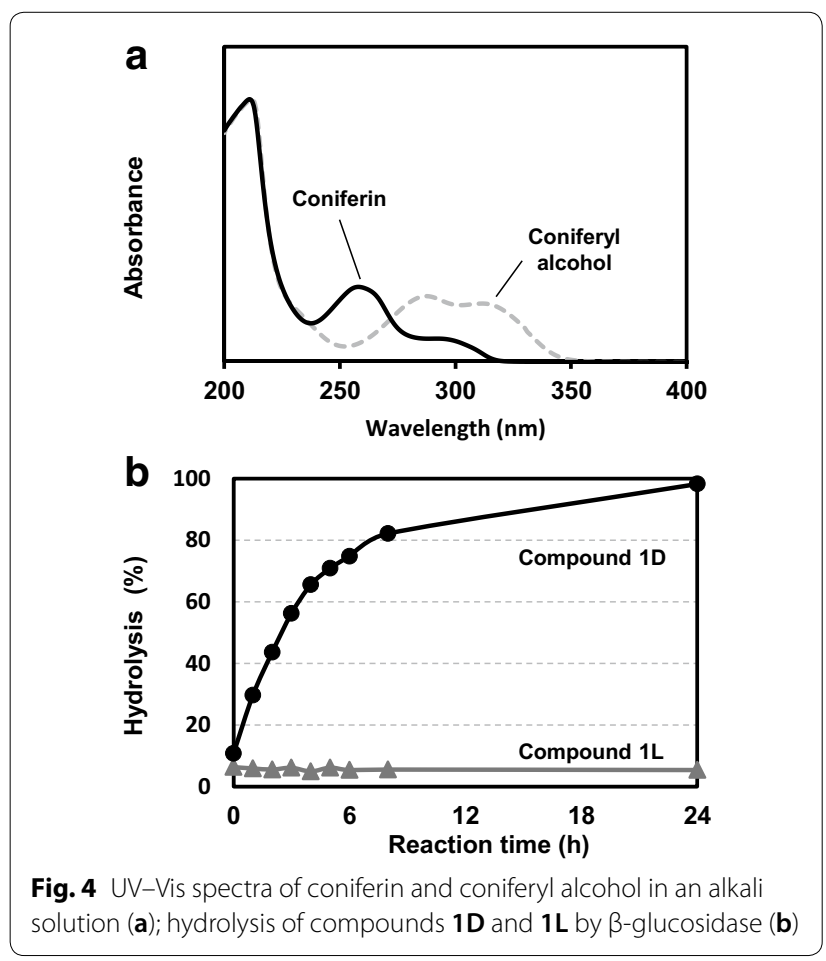

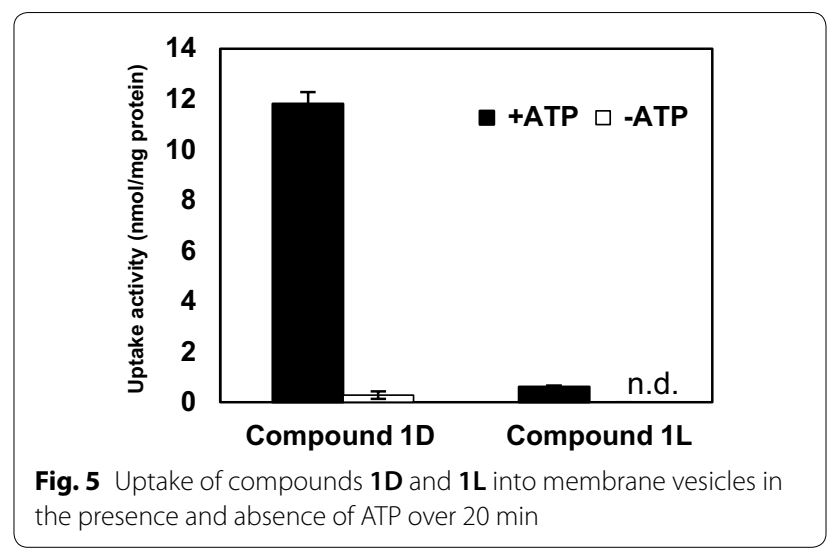

compounds 1L and 1D in the presence of ATP, although compound $1 \mathrm{~L}$ is an enantiomer of compound 1D. Previous study indicated that transport of compound 1D is involved in vacuolar type $\mathrm{H}^{+}$-ATPase which is localized not only vacuolar membrane but also endoplasmic reticulum, Golgi apparatus, and other endomembrane systems [3]. Although it is indistinct whether transport activity of compound 1D shows transport into vacuole and/or other endomembrane systems, compound $1 \mathrm{~L}$ was not transported across the crude microsomal membranes containing plasma membrane, vacuolar membrane, Golgi membrane and other endomembranes obtained from differentiating xylem of hybrid poplar. Therefore, the $\mathrm{D}-/ \mathrm{L}-$ configuration of the sugar moiety of coniferin was strictly recognized during the coniferin transport process across the membrane in the present assay.

\section{Conclusions}

Compound 1L was successfully prepared according to the conventional method for compound 1D. Compound 1L was not found to be useful as a transport tracer in an administration experiment, although compound $\mathbf{1 L}$ was resistant toward enzymatic hydrolysis by commercial $\beta$-glucosidase from Almond. However, the $\mathrm{D}-/ \mathrm{L}$-configuration of the sugar moiety of coniferin was found to be a factor that affected coniferin transport across the membrane. This new finding might provide supporting evidence that compound 1D is a transport form of coniferyl alcohol.

\section{Additional file}

Additional file 1. Additional figures.

Abbreviations

MALDI-TOF MS: matrix-assisted laser desorption/ionization time-of-flight mass spectrometry; m.p.: melting point. 


\section{Acknowledgements}

The authors thank to JSPS Grant-in-Aid for Challenging Research 18K19230.

\section{Authors' contributions}

HM contributed to preparation of D- and L-coniferin and their enzymatic hydrolysis experiments. HK supported to HM's experiments. TT and KT contributed to transport assay. TT (corresponding author) designed this study and wrote this paper. All authors read and approved the final manuscript.

\section{Funding}

This work was supported by a JSPS Grant-in-Aid for Challenging Research 18 K19230.

\section{Availability of data and materials}

The datasets used and/or analyzed during the current study are available from the corresponding author on reasonable request.

\section{Competing interests}

The authors declare that they have no competing interests.

\section{Author details}

${ }^{1}$ Division of Forest and Biomaterials Science, Graduate School of Agriculture, Kyoto University, Kitashirakawa oiwake-cho, Sakyo-ku, Kyoto 606-8502, Japan. 2 Department of Forest and Environmental Sciences, Faculty of Agriculture, University of Miyazaki, 1-1 Gakuenkibanadai-nishi, Miyazaki 889-2192, Japan.

Received: 29 March 2019 Accepted: 8 July 2019

Published online: 17 July 2019

\section{References}

1. Whetten RW, Mackay JJ, Sederoff RR (1998) Recent advances in understanding lignin biosynthesis. Annu Rev Plant Physiol Plant Mol Biol 49:585-609. https://doi.org/10.1146/annurevarplant.49.1.585

2. Aoki D, Hanaya Y, Akita T, Matsushita Y, Yoshida M, Kuroda K, Yagami S, Takana R, Fukushima K (2016) Distribution of coniferin in freesed-fixed stem of Ginkgo biloba L. by cryo-TOF-SIMS/SEM. Sci Rep 6:31525. https:// doi.org/10.1038/srep31525

3. Tsuyama T, Kawai R, Shitan N, Matoh T, Sugiyama J, Yoshinaga A, Takabe K, Fujita M, Yazaki K (2013) Proton-dependent coniferin transport, a common major transport event in differentiating xylem tissue of woody plants. Plant Physiol 162:918-926. https://doi.org/10.1104/pp.113.214957

4. Terashima N, Ko C, Matsushita Y, Westermark U (2016) Monolignol glucoside as intermediate compounds in lignin biosynthesis. Revisiting the cell wall lignification and new ${ }^{13} \mathrm{C}$-tracer experiments with Ginkgo biloba and Magonolia liliiflora. Holzforshung 70:801-810. https://doi.org/10.1515/ hf-2015-0224

5. Tsuyama T, Takabe J (2014) Distribution of lignin and lignin precursors in differentiating xylem of Japanese cypress and poplar. J Wood Sci 60:353-361. https://doi.org/10.1007/s10086-014-1417-z

6. Samuels AL, Rensing KH, Douglas CJ, Mansfield SD, Dharmawardhana DP, Ellis BE (2012) Cellular machinery of wood production: differentiation of secondary xylem in Pinus contorta var. latifolia. Planta 216:72-82. https:// doi.org/10.1007/s00425-002-0884-4

7. Tsuyama T, Takabe J (2015) Coniferin $\beta$-glucosidase is ionically bound to cell wall in differentiating xylem of poplar. J Wood Sci 61:438-444. https ://doi.org/10.1007/s10086-015-1486-7

8. Fukushima K, Terashima N (1991) Heterogeneity in formation of lignin Part XV: formation and structure of lignin in compression wood of Pinus thunbergii studied by microautoradiography. Wood Sci Technol 25:371-381

9. Okada M, Sumitomo H, Hirasawa T (1986) Chemical synthesis of polysaccharides 7. Enzymatic hydrolysis of $(1 \rightarrow 6)$-a-DL-glucopyranan (DL-dextran). Biopolymers 25:1955-1965. https://doi.org/10.1002/bip.360251010

10. Terashima N, Ralph SA, Landucci LL (1996) New facile syntheses of monolignol glucosides; p-glucocoumaryl alcohol, coniferin, and syringin. Holzforshung 50:151-155

11. Xia T-Y, Li YB, Yin ZJ, Meng XB, Li SC, Li ZJ (2014) Synthesis of L-glucose and L-galactose derivatives from D-sugars. Chin Chem Lett 25:1220-1224. https://doi.org/10.1016/j.cclet.2014.06.007

12. Miyagawa Y, Mizukami T, Kamitakahara H, Takano T (2014) Synthesis and fundamental HSQC NMR data of monolignol $\beta$-glycosides, dihydromonolignol $\beta$-glycosides and $p$-hydroxybenzaldehyde derivative $\beta$-glycosides for the analysis of phenyl glycoside type lignin-carbohydrate complexes (LCCs). Holzforshung 68:747-760. https://doi.org/10.1515/hf-2013-0164

13. Otani M, Shitan N, Sakai K, Martinoia E, Sato F, Yazaki K (2005) Characterization of vacuolar transport of the endogenous alkaloid berberine in Coptis japonica. Plant Physiol 138:1939-1946. https://doi.org/10.1104/ pp.105.064352

14. Rathore H, Hashimoto T, Igarashi K, Nukaya H, Fullerton DS (1985) Cardiac glycosides: 5 . Stereoselective syntheses of digitoxigenin $a-D-, \beta-D-, a-L$, and $\beta$-L-glucosides. Tetrahedron 41:5427-5438. https://doi.org/10.1016/ s0040-4020(01)91342-0

\section{Publisher's Note}

Springer Nature remains neutral with regard to jurisdictional claims in published maps and institutional affiliations.

\section{Submit your manuscript to a SpringerOpen ${ }^{\circ}$ journal and benefit from:}

- Convenient online submission

- Rigorous peer review

- Open access: articles freely available online

- High visibility within the field

- Retaining the copyright to your article

Submit your next manuscript at springeropen.com 